\title{
Effect of Plasma Treatment on Growth and Yield of Okra [Abelmoschus esculentus (L.) under Field Conditions
}

\author{
Ravinder Kumar ${ }^{1 *}$, Ashok K. Thakur ${ }^{1}$, Amit Vikram², A. Vaid ${ }^{3}$ and R. Rane ${ }^{3}$ \\ ${ }^{1}$ Dept. of Seed Science and Technology, ${ }^{2}$ Dept. of Vegetable Science, Dr. Y. S. Parmar University of Horticulture and Forestry, \\ Solan, Himachal Pradesh (173 230), India \\ ${ }^{3}$ FCIPT, Institute for Plasma Research, Gandhinagar, Gujarat (382 044), India
}

\section{Corresponding Author}

Ravinder Kumar

e-mail: ravisehrawat.hau@gmail.com

\author{
Article History \\ Article ID: AR1836 \\ Received in $24^{\text {th }}$ August, 2017 \\ Received in revised form $27^{\text {th }}$ September, 2017 \\ Accepted in final form $2^{\text {nd }}$ October, 2017
}

\begin{abstract}
This study investigated the effect of cold plasma treatment on growth and fruit yield characters of okra [Abelmoschus esculentus (L.) cultivar P-8]. The experiment comprising of seeds of two different ageviz., 'A1' (One year old seed) and 'A2' (Two year old seed) and seven plasma treatments of seeds viz., 'P1' (only vacuum, no plasma treatment), 'P2' (3 minute), 'P3' (6 minute), 'P4' (9 minute), 'P5' (12 minute), 'P6' (15 minute) and 'P7' (Control-Without treatment) during 2014. The seeds with different combination of treatments were evaluated for different growth and yield parameters. It has been observed that the plasma treatment of 12 minutes duration on A1 seeds could significantly improve total emergence (27.72\%), early days to $50 \%$ flowering and first fruit picking as compared to control. The plant height at final harvest (25.99\%), harvest duration (25.38\%), number of fruits plant ${ }^{-1}(40.29 \%)$, fruit weight (19.67\%) and fruit yield plant ${ }^{-1}$ (8.16\%) was significantly increased as compared to control. These results also indicated that cold plasma treatment might promote the growth and modify the speed of germination. It was also found that there is no significant effect of plasma take place on number of node to first flower, number of branches, fruit length and fruit diameter. Therefore, our results show that cold plasma treatment has important application prospects for increasing fruit yield of okra.
\end{abstract}

Keywords: Cold plasma, seed treatment, okra, plant growth, yield

\section{Introduction}

Okra [Abelmoschus esculentus (L.) Moench], a member of the family Malvaceae and is native to South Africa and Asia. It is an important vegetable crop throughout the tropics and sub tropics (Kochhar, 1986; Hammon and Van Sloten, 1989). Hence, the quality of seed is of utmost importance to have good and uniform crop stand. In some cultivars, the occurrence of hard seeds becomes more frequent the longer the pods remain in the plant (Luis Felipe et al., 2010). Hardseededness can be variable in a population of seeds.The degree of hardness is increased by environmental (dry) conditions during seed maturation and seed storage (Baskin and Baskin, 1998). Temperature during germination is another important factor that governs the germination. The best temperature for germination of okra seeds ranges from $25-35{ }^{\circ} \mathrm{C}$ and quick germination is observed at $35{ }^{\circ} \mathrm{C}$ (Mereddy et al., 2000). However, when okra seeds are sown in early spring season, the prevailing low temperature hampers germination and vigour of seeds and ultimately the crop stand. The vegetative traits are also a measure of yield and should be considered, just as pod characteristics, during selection in breeding programmes to improve yield (Ariyo, 1992). The weight of the pod and the number of pods plant ${ }^{-1}$ has been consistently identified as very important components of pod yield (Kaul et al., 1978; Ariyo, 1989). Number of pods plant ${ }^{-1}$, days to flowering and plant height are some of the most variable quantitative characters of okra (Singh and Singh, 1977). Mishra and Chhonkar (1979) reported considerable variation in okra vegetative and fruit characters. Setubal et al. (1994) observed that the proportion of hard seeds significantly increased when the harvesting was delayed until senescence of the plant.

There are different seed enhancement technologies like coating, pelleting, priming etc which increases the moisture content of the seed during treatment. Here, a dry seed treatment i.e. plasma treatment is employed to increase the seed coat permeability without increasing the moisture content of seed. The method of Plasma seed treatment is a physico-chemical method which has potential to improve germination yields and kill fungal spores carried on seed coats (Griesser et al., 2011). Cold plasma seed treatment is a modern eco-agricultural high technique that could increase 
crop yields (Jiafeng J et al., 2014). A positive effect of low temperature plasma treatment on germination of various agricultural crops has been found (Sera B et al., 2003). Today, plasma is used for varieties of industrial applications ranging from arc welding, metal hardening, nuclear fusion, creation of nano structure, functional polymer coating and change in surface hyrdrophilicity (Filatova I et al., 2010). Hence, effect of cold plasma treatment on growth and yield characters of okra seeds was studied.

\section{Materials and Methods}

Seeds of okra [Abelmoschus esculentus (L.)Moench] and (cultivar P-8) were obtained from Dr. Y.S. Parmar university of Horticulture and Forestry Himachal Pradesh, India and were exposed to cold plasma treatment under the following parameters: Glow Discharge plasma of oxygen gas was used at a base pressure of $0.05 \mathrm{~m}$ bar, operating pressure $0 \mathrm{f} 0.2$ $\mathrm{m}$ bar, voltage of $500 \mathrm{~V}$, current of $0.2 \mathrm{~A}$ and power of $100 \mathrm{~W}$ for treatment durations of 0, 3, 6, 9, 12 and 15 minutes. The plasma treatment was done at FCIPT (Facilitation Centre for Industrial Plasma Technologies), Institute for Plasma Research, Gandhinagar, Gujarat, India (An Institute under Department of Atomic Energy, GOI). The field experiment was conducted during July, 2014-15 at Agricultural Research Farm, Dr Y. S. Parmar university of Horticulture and Forestry, Himachal Pradesh, India in Randomized Block Design (Factorial) with seven treatments replicated four times in each. The farm is located at an altitude of 1183 meters above mean sea level with latitude of $30.51^{\circ} \mathrm{N}$ and longitude of $77.09{ }^{\circ} \mathrm{E}$ the midhill zone of Himachal Pradesh, India observed with GARMIN'S GPS 12 Personal Navigator. During the crop season (JulyOctober), the maximum average temperature $\left(23.7^{\circ} \mathrm{C}\right.$ ) was recorded in the month of August, 2014 and lowest average temperature in October, $2014\left(18^{\circ} \mathrm{C}\right)$; the average rainfall was maximum (361 $\mathrm{mm}$ ) in July month and lowest $(15.7 \mathrm{~mm})$ in October and the average relative humidity was maximum (76\%) in July and lowest in October (60\%).

The seeds of okra were sown as per the treatments in a plot having size of $2.0 \times 2.4 \mathrm{~m}^{2}$ i.e. $4.8 \mathrm{~m}^{2}$. FYM and fertilizers were applied as per package of practices for vegetable crops, Directorate of Extension Education, Dr. Y. S. Parmar University of Horticulture and Forestry, Nauni, Solan (HP) (FYM @ 100 quintal per ha, CAN@300 kg ha-1, SSP@315 kg ha-1 and MOP@ $90 \mathrm{~kg} \mathrm{ha}^{-1}$ ).

\section{Results and Discussion}

\subsection{Total emergence (\%)}

The result on total emergence as influenced by age of seed, plasma treatments and their interactions are presented in Table 1. Total emergence of okra seed exposed to plasma was significantly higher in one year old seed $(85.96 \%)$ than that of two year old seed (73.57\%).

Significant variations for total emergence were observed among all the plasma treatments. Higher emergence was recorded in the seed exposed to plasma for 12 minutes $(89.00 \%)$, which was at par with 9 minutes exposure time (83.43\%) and the seed exposed for 15 minutes to plasma showed significant lower percent germination (81.87\%), which was at par with 9 minute $(83.43 \%)$ and 6 minute $(81.25 \%)$ and 3 minute (79.06\%) treatment. The seed which was kept under vacuum and not exposed to plasma showed significantly lower total emergence (74.06\%) compared to plasma treated seeds, which was at par with 3 minutes (79.06\%). The lowest value of seed emergence (69.68\%) was observed in control.

Total emergence (\%) is an important character as optimum plant population is a pre-requisite for the efficient use of resources and eventually increased yield. The efficient use of resources and increased yield can only be achieved when there is optimum plant population. Total emergence percent was found to be reduced from $85.96 \%$ to $73.57 \%$ with increasing seed age from one year old seed to two year old seed. There was considerable reduction in total emergence in two year old seeds. Such decline in field emergence was due to reduced germination and seedling vigour as observed by Karuna and Aswathaiah (1989) in beetroot and carrot. The progressive reduction in field emergence due to low vigour levels are in accordance with the earlier findings of Schuch and Lin (1982) in wheat. The reduction in field emergence might be due to the initial slow growth rate in old seeds which tends to continue during ontogenetic development of seedling (Heydecker, 1972). All the plasma treatments significantly enhanced emergence percentage irrespective of ageing. The maximum emergence was recorded in 12 minutes plasma exposure and minimum emergence was observed in control i.e. untreated seeds. Beyond 12 minute plasma treatment, there was a gradual decrease in emergence percentage. According to Filatova et al. (2013), decrease in germination after certain period of time in wheat is due to damage of seed inflicted by plasma bombardment. Plasma induces a range of biochemical changes in the seed that are required to start the germination process like, internal physiological change connected with seed hormonal activities and enzymes activation (Zivkovic et al., 2004); (Sera et al., 2008). Thus, upon seeding, plasma seeds can rapidly imbibe water and revive the seed metabolism, resulting in a higher germination rate and a reduction in the inherent physiological heterogeneity in germination (Spatenka et al., 2008). The study of interaction effects between ageing and plasma treatments was found to be non-significant.

\subsection{Days to $50 \%$ flowering}

The data on days to $50 \%$ flowering as influenced by age of seed, plasma treatments and their interactions are presented in Table 1. Days to 50\% flowering differed significantly between one year and two year old seed. The minimum mean days to $50 \%$ flowering (45.32) was observed in one year old seed and on the other hand highest days to $50 \%$ flowering (46.43) was recorded with two year old seed. 


\begin{tabular}{|c|c|c|c|c|c|c|c|c|c|}
\hline $\begin{array}{l}\text { Plasma } \\
\text { treatment } \\
\text { Durations } \\
\end{array}$ & \multicolumn{3}{|c|}{ Total emergence (\%) } & \multicolumn{3}{|c|}{ Days to $50 \%$ flowering } & \multicolumn{3}{|c|}{ Days to first fruit picking } \\
\hline (P) & \multirow{2}{*}{$\begin{array}{l}\text { One year } \\
\text { Seed }\left(A_{1}\right)\end{array}$} & \multirow{2}{*}{$\begin{array}{l}\text { Two year } \\
\text { Seed }\left(A_{2}\right)\end{array}$} & Mean & \multirow{2}{*}{$\begin{array}{l}\text { One year } \\
\text { Seed }\left(A_{1}\right)\end{array}$} & \multirow{2}{*}{$\begin{array}{l}\text { Two year } \\
\text { Seed }\left(A_{2}\right)\end{array}$} & \multirow{2}{*}{$\begin{array}{c}\text { Mean } \\
(\mathrm{P})\end{array}$} & \multirow{2}{*}{$\begin{array}{l}\text { One year } \\
\text { Seed }\left(A_{1}\right)\end{array}$} & \multirow{2}{*}{$\begin{array}{l}\text { Two year } \\
\text { Seed }\left(A_{2}\right)\end{array}$} & \multirow{2}{*}{$\begin{array}{c}\text { Mean } \\
(\mathrm{P})\end{array}$} \\
\hline & & & $(\mathrm{P})$ & & & & & & \\
\hline Vacuum & $80.62(9.03)$ & $67.50(8.27)$ & $74.06(8.65)^{\mathrm{ab}}$ & 48.25 & 49.25 & $48.75^{\mathrm{e}}$ & 68.75 & 70.50 & $69.63^{d}$ \\
\hline 3 minutes & $86.25(9.33)$ & $71.87(8.53)$ & $79.06(8.93)^{\mathrm{bc}}$ & 46.50 & 47.00 & $46.75^{d}$ & 66.00 & 67.00 & $66.50^{c}$ \\
\hline 6 minutes & $86.87(9.36)$ & $75.62(8.74)$ & $81.25(9.05)^{c}$ & 44.75 & 45.75 & $45.25^{c}$ & 63.75 & 65.00 & $64.38^{\mathrm{bc}}$ \\
\hline 9 minutes & $88.75(9.46)$ & $78.12(8.89)$ & $83.43(9.18)^{c d}$ & 43.25 & 44.00 & $43.63^{b}$ & 61.75 & 63.00 & $62.38^{b}$ \\
\hline 12 minutes & 95.50(9.82) & $82.50(9.13)$ & $89.00(9.47)^{d}$ & 41.25 & 42.75 & $42.00^{\mathrm{a}}$ & 57.00 & 59.50 & $58.25^{\mathrm{a}}$ \\
\hline 15 minutes & $86.25(9.34)$ & $77.50(8.85)$ & $81.87(9.09)^{c}$ & 44.00 & 46.00 & $45.00^{b c}$ & 62.75 & 65.75 & $64.25^{\mathrm{bc}}$ \\
\hline $\begin{array}{l}\text { Control } \\
\text { (untreated) }\end{array}$ & $77.50(8.85)$ & $61.87(7.92)$ & $69.68(8.39)^{a}$ & 49.25 & 50.25 & $49.75^{\mathrm{e}}$ & 69.25 & 71.25 & $70.25^{d}$ \\
\hline $\begin{array}{l}\text { Mean } \\
\text { (A) }\end{array}$ & $85.96(9.31)^{\mathrm{A}}$ & $73.57(8.62)^{\mathrm{B}}$ & & $45.32 \mathrm{~A}$ & $46.43 \mathrm{~B}$ & & $64.18 \mathrm{~A}$ & $66.00 \mathrm{~B}$ & \\
\hline \multirow[t]{3}{*}{$\mathrm{CD}(p=0.05)$} & (A) & \multicolumn{2}{|c|}{0.16} & \multicolumn{3}{|c|}{0.78} & \multicolumn{3}{|c|}{1.64} \\
\hline & $(\mathrm{P})$ & \multicolumn{2}{|c|}{0.30} & \multicolumn{3}{|c|}{1.47} & \multicolumn{3}{|c|}{3.07} \\
\hline & $(\mathrm{AxP})$ & \multicolumn{2}{|c|}{ NS } & \multicolumn{3}{|c|}{ NS } & \multicolumn{3}{|c|}{ NS } \\
\hline
\end{tabular}

Parenthesis are square root transformed

A significant improvement in days to $50 \%$ flowering was observed due to plasma over control. Seed exposed to plasma for 12 minutes recorded minimum days to $50 \%$ (42.00) and the seed which was kept under vacuum and not exposed to plasma showed significantly maximum days to $50 \%$ flowering (48.75). The maximum days to $50 \%$ flowering (49.75) was recorded in control seed where no vacuum and no plasma treatment were given.

Earliness is an important character and an indicator of getting early and higher yields in okra. Days to $50 \%$ flowering differed significantly between one year old seed and two year old seed. Fifty percent flowering appeared early (45.32 days) in one year old seed as compared to two year old seed (46.43 days). Delayed flowering might be due to low initial seedling vigour and productivity status of aged seeds. The main cause can be the deterioration of the seeds due to ageing. Edje and Burris (1970) reported that ageing causes decline in emergence and flowering in soybean. All the plasma treatments significantly reduced days to $50 \%$ flowering irrespective of seed ageing compared to untreated seeds. The early $50 \%$ flowering $(42.00$ days after sowing) was recorded in 12 minutes plasma treated seeds and delayed $50 \%$ flowering of 49.75 days after sowing was recorded in control. The early flowering in the crop raised from the plasma treated seeds may be due to the completion of pre-germination metabolic activities making the seeds ready for radicle protrusion and the plasma treated seed germinated earlier as compared to untreated dry seeds (Sera et al., 2012). These positive effects are probably due to the stimulatory effects of plasma on the early stages of germination process by mediation of cell division in germinating seeds (Dubinov et al., 2000). Non-significant interaction of age of seed and plasma exposure time were observed for days to $50 \%$ flowering.

\subsection{Days to first fruit picking}

The data on days to first fruit picking as influenced by age of seed, plasma treatments and their interactions are presented in Table 1. The data revealed that the early first picking is done (64.18 days) in one year old seed and late first picking (66.00 days) is done in two year old seed.

Days to first picking were differed significantly due to different plasma exposure. Early first picking ( 58.25 days) was recorded in seed exposed to plasma for 12 minutes, whereas delayed first picking ( 69.63 days) was observed in vacuum seed where no plasma treatment were given. Seed exposed to plasma for 15 minutes recorded 64.25 days to first picking which was at par with 9 minute ( 62.38 days) and 6 minute (64.38 days) treatment. However delayed first picking (70.25 days) was observed in control seed where no vacuum and no plasma treatment were given.

Early maturity is desirable trait which fetches good yield and returns to the growers. Days to first picking differed significantly between one year and two year old seeds. The data revealed that fruits were ready for marketing in (64.18 days after sowing) in one year old seed and in 66.00 days after sowing in two year old seeds. This is on account of delayed flowering in two year old seeds as a result of low initial seedling 
vigour and productivity status of aged seeds. The data showed the best result in 12 minute plasma treatment recording 58.25 days to first picking while control stood the minimum observing 70.25 days to first picking. The probable reason for early maturity of plasma treated seed plants may be due to the fact that the plants of plasma treated seeds took fewer days to emerge and flower therefore it matured earlier than the plants of untreated seeds. Interaction effects between aged and plasma treatments were found to be non-significant for days to first picking.

\subsection{Plant height at 30 days after sowing}

Observation recorded on plant height at 30 days after sowing as influenced by age of seed, plasma treatments and their interactions are presented in Table 2. Significantly higher plant height at 30 days after sowing $(17.89 \mathrm{~cm})$ was recorded with one year old seed as compared with two year old seed $(15.02 \mathrm{~cm})$.

The plant height at 30 days after sowing differed significantly due to different plasma exposure time on seed. Seed exposed to plasma for 12 minutes recorded highest plant height (18.43 $\mathrm{cm})$ which was at par with 9 minutes $(17.82 \mathrm{~cm}), 6$ minutes $(17.25 \mathrm{~cm})$ and 15 minutes $(17.05 \mathrm{~cm})$ treatment. The seed which was kept under vacuum and not exposed to plasma showed significantly low plant height $(14.81 \mathrm{~cm})$ compared to plasma treated seeds. The lowest plant height $(14.20 \mathrm{~cm})$ was observed in control seed where no plasma treatment was given.

Plant height at 30 days after sowing (DAS) is an indicator of vigorous and early growth associated with fast emergence of seedlings. Seed ageing differed substantially for plant height at 30 days after sowing. Results revealed reduction in plant height from $17.89 \mathrm{~cm}$ to $15.02 \mathrm{~cm}$ with increase in ageing level from one year old seed than two year old seed.The results are in conformity with the findings of Tekroni et al. (1989) in corn. All the seed plasma treatments significantly improved plant height at 30 DAS irrespective of ageing. The maximum plant height at 30 DAS $(18.43 \mathrm{~cm})$ was recorded in 15 minutes plasma exposure seeds and minimum $14.20 \mathrm{~cm}$ in control. Similar findings of increase in plant height in tomato seedlings were reported by Zhou et al. (2011). This might be happened due to the active oxygen particles that penetrate into the seeds, accelerate to decompose the inner nutriment of the seeds, reduce relative penetrability of cell velum, and improve the activities of the root of the tomato seedling (Zhou et al., 2011).

However the interaction effects of age of seed and plasma exposure time were statistically non-significant at $5 \%$ level of significance.

\subsection{Plant height at final harvest}

The results on plant height at final harvest after sowing as influenced by age of seed, plasma treatments and their interactions are presented in Table 2 . Significantly higher plant height at final harvest after sowing $(135.96 \mathrm{~cm})$ was recorded with one year old seed as compared with two year old seed $(126.96 \mathrm{~cm})$.

The exposure time of plasma to the seed, significantly

Table 2: Effect of seed age and plasma treatment on fruit yield characters in okra

\begin{tabular}{|c|c|c|c|c|c|c|c|c|c|}
\hline Plasma & \multicolumn{3}{|c|}{ Plant height 30 DAS } & \multicolumn{3}{|c|}{ Plant height at final harvest } & \multicolumn{3}{|c|}{ No. of node to first flower } \\
\hline Durations & & $(\mathrm{cm})$ & & & $(\mathrm{cm})$ & & & & \\
\hline \multirow[t]{2}{*}{ (P) } & \multirow{2}{*}{$\begin{array}{l}\text { One year } \\
\text { seed }\left(A_{1}\right)\end{array}$} & \multirow{2}{*}{$\begin{array}{l}\text { Two year } \\
\text { seed }\left(A_{2}\right)\end{array}$} & Mean & \multirow{2}{*}{$\begin{array}{l}\text { One year } \\
\text { seed }\left(A_{1}\right)\end{array}$} & \multirow{2}{*}{$\begin{array}{l}\text { Two year } \\
\text { seed }\left(A_{2}\right)\end{array}$} & Mean & \multirow{2}{*}{$\begin{array}{l}\text { One year } \\
\text { seed }\left(A_{1}\right)\end{array}$} & \multirow{2}{*}{$\begin{array}{l}\text { Two year } \\
\text { seed }\left(A_{2}\right)\end{array}$} & \multirow{2}{*}{$\frac{\text { Mean }}{(\mathrm{P})}$} \\
\hline & & & $(P)$ & & & $(P)$ & & & \\
\hline Vacuum & 15.43 & 14.19 & $14.81^{\mathrm{a}}$ & 125.45 & 117.90 & $121.68^{a}$ & 7.75 & 7.75 & 7.75 \\
\hline 3 minutes & 16.85 & 14.35 & $15.60^{\mathrm{ab}}$ & 128.66 & 121.50 & $125.08^{a b}$ & 7.50 & 7.50 & 7.50 \\
\hline 6 minutes & 18.97 & 15.54 & $17.25^{c}$ & 134.21 & 128.73 & $131.47^{\mathrm{ab}}$ & 8.25 & 8.00 & 8.13 \\
\hline 9 minutes & 19.54 & 16.10 & $17.82^{c}$ & 142.51 & 133.28 & $137.89^{b c}$ & 7.50 & 7.75 & 7.63 \\
\hline 12 minutes & 20.17 & 16.69 & $18.43^{c}$ & 161.69 & 141.55 & $151.62^{c}$ & 7.75 & 7.75 & 7.75 \\
\hline 15 minutes & 19.29 & 14.81 & $17.05 b^{c}$ & 135.58 & 128.73 & $132.15^{\mathrm{ab}}$ & 7.50 & 7.50 & 7.50 \\
\hline $\begin{array}{l}\text { Control } \\
\text { (untreated) }\end{array}$ & 14.97 & 13.44 & $14.20^{\mathrm{a}}$ & 123.63 & 117.05 & $120.34^{a}$ & 7.50 & 7.75 & 7.63 \\
\hline Mean & $17.89^{\mathrm{A}}$ & $15.02^{\mathrm{B}}$ & & $135.96^{\mathrm{A}}$ & $126.96^{\mathrm{B}}$ & & 7.68 & 7.71 & \\
\hline (A) & & & & & & & & & \\
\hline \multirow[t]{3}{*}{$\operatorname{CD}(p=0.05)$} & (A) & \multicolumn{2}{|c|}{0.82} & \multicolumn{3}{|c|}{8.43} & \multicolumn{3}{|c|}{ NS } \\
\hline & $(P)$ & \multicolumn{2}{|c|}{1.54} & \multicolumn{3}{|c|}{15.78} & \multicolumn{3}{|c|}{ NS } \\
\hline & $(\mathrm{AxP})$ & \multicolumn{2}{|c|}{ NS } & \multicolumn{3}{|c|}{ NS } & \multicolumn{3}{|c|}{ NS } \\
\hline
\end{tabular}


influenced the plant height at final harvest. Seed exposed to plasma for 12 minutes recorded highest plant height (151.62 $\mathrm{cm}$ ) which was at par with 9 minutes $(137.89 \mathrm{~cm})$ treatment. The seed which was kept under vacuum and not exposed to plasma showed significantly low plant height $(121.68 \mathrm{~cm})$ compared to plasma treated seeds. The lowest plant height $(120.34 \mathrm{~cm})$ was observed in untreated seeds i.e. control. The results are in conformity with the findings of Tekroni et al. (1989) in corn. All the seed plasma treatments significantly improved plant height at final harvest irrespective of ageing. Similar findings of increase in plant height in tomato seedlings were reported by Zhou et al. (2011). It might be happened due to the active oxygen particles that penetrate into the seeds, accelerate to decompose the inner nutriment of the seeds, reduce relative penetrability of cell velum, and improve the activities of the root of the tomato seedling (Zhou et al., 2011).

\subsection{No. of node to first flower}

The results on node at which first flower appearedas influenced by age of seed, plasma treatments and their interactions are presented in Table 2. Seed age and different exposure of plasma on okra seed showed non-significant results on node at which first flower.

However, the interaction effects due to age of seed and plasma exposure time were found to be non-significant at $5 \%$ level of significance.

\subsection{No. of branches plant ${ }^{-1}$}

Data pertaining to number of branches as influenced by age of seed, plasma treatments and their interactions are presented in Table 3. Age of seed and different exposure of plasma on okra seed showed no significant results on number of branches. The maximum number of branches (5.0) was observed in one year old seed. While minimum number of branches (2.5) was recorded in two year old seed. These effects are probably due to non-stimulatory effects of plasma on branches during plant development (Dubinov et al., 2000).

\subsection{Harvest duration}

The results on harvest duration as influenced by age of seed, plasma treatments and their interactions are presented in Table 3. Harvest duration differed significantly due to aged seed. The maximum harvest duration (47.46 days) was observed in one year old seed. While, minimum harvest duration (45.68 days) was recorded in two year old seed.

A significant improvement in harvest duration was observed due to different plasma exposure over control (41.75 days) seed where no vacuum and no plasma treatment were given. Seed exposed to plasma for 12 minutes recorded maximum harvest duration (52.38 days) which was at par with 9 minutes (50.88 days) treatment. The seed which was kept under vacuum and not exposed to plasma showed lowest harvest duration (43.75 days) compared to plasma treated seeds.

Longer harvest duration is a more desirable trait for continuous supply of fresh okra fruits to market over longer periods

Table 3: Effect of seed age and plasma treatment on number of branches and harvest duration and no.of fruits plant ${ }^{-1}$ in okra

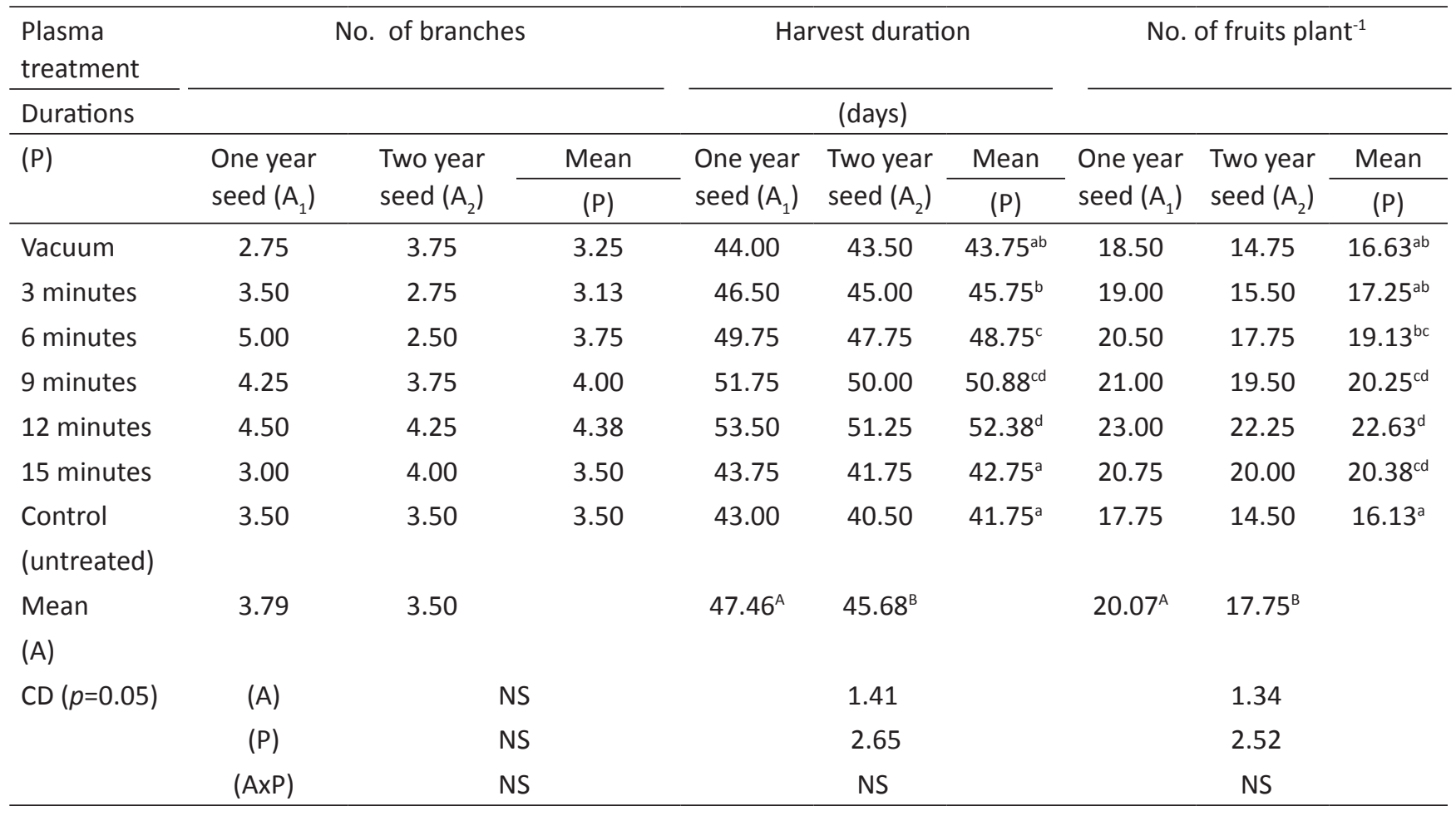


and harvest duration determines the time period for which the marketable fruits could be harvested so as to meet the market trends. Harvest duration differed significantly between one year and two year old seeds. The data revealed that the longer harvest duration of 47.46 days in one year old seed as compared to 45.68 days in two year old seed. This is on account of early flowering in one year old seeds as a result of high initial seedling vigour and productivity status of seeds. Early flowering further led to early fruit set thereby leading to longer harvest duration in crop raised from one year old seeds. The data recorded revealed that longest harvest duration of 52.38 days was observed in seeds exposed to 12 minutes plasma. On the other hand, control recorded the shortest harvest duration of 41.75 days. The longer harvest duration may be due to early flowering and subsequently healthier crop growth. It might be due to early emergence and more harvest duration was found in one year old seed. Similar results were observed by Rodriguez and McDonald (1989) and they recorded maximum harvest duration of bean seeds.

The interaction effects due to age of seed and plasma exposure time were found to be non-significant at $5 \%$ level of significance.

\subsection{No. of fruits plant ${ }^{-1}$}

The data representing number of fruits plant ${ }^{-1}$ as influenced by age of seed, plasma treatments and their interactions are presented in Table 3 . The maximum number of fruits plant ${ }^{-1}$ (20.07) was observed in one year old seed while minimum number of fruits plant ${ }^{-1}$ (17.75) was recorded with two year old seed.

Number of fruits plant ${ }^{-1}$ differed significantly due to different exposure of plasma treatments. Seeds exposed to plasma for 12 minutes recorded maximum number of fruits plant ${ }^{-1}$ (22.63) which was at par with 15 minutes (20.38) and 9 minutes (20.25) treatment. The seed which was kept under vacuum and not exposed to plasma recorded minimum number of fruits per plant (16.63) compared to plasma treated seeds. While the minimum fruits plant ${ }^{-1}(16.13)$ was recorded in control seed where no treatment were given.

Both production and productivity were significantly influenced by higher no. of fruits plant ${ }^{-1}$. This is one of the most important characters contributing directly to higher yields. Number of fruits plant ${ }^{-1}$ differed significantly between one year and two year old seeds. The maximum number of fruits plant ${ }^{-1}$ (20.07) was recorded in crop raised from one year old seeds and lowest (17.75) recorded in crop raised from two year old seeds. It might be due to early emergence and more harvest duration was found in one year old seed. Similar results were observed by Hussaini et al. (1988) and they recorded decrease in fruit yield of stored maize seeds. Highest number of fruits plant $^{-1}(22.63)$ was observed in seeds treated with 12 minutes plasma exposure and lowest (16.63) in control. The increase in number of fruits per plant with seed plasma may be due to early field emergence and more harvest duration. Interaction effects between aged and plasma treatments were found to be non-significant for number of fruits plant ${ }^{-1}$.

\subsection{Fruit length}

Observations recorded for fruit length as influenced by age of seed, plasma treatments and their interactions are presented in Table 4. Age of seed and different exposure of plasma on okra seed showed no significant results on fruit length. While, the maximum fruit length was observed in one year old seed $(19.26 \mathrm{~cm})$ and minimum fruit length was observed in two year old seed $(15.00 \mathrm{~cm})$.

Interaction effects of age of seed and plasma exposure time were statistically non significant at $5 \%$ level of significance.

\subsection{Fruit diameter}

The results for fruit diameter as influenced by age of seed, plasma treatments and their interactions are presented in Table 4. Age of seed and different exposure of plasma on okra seed showed non-significant results on fruit diameter. Okra seed exposed to plasma treatments was significantly higher in one year old seed $(2.41 \mathrm{~cm})$ than that of two year old seed $(1.91 \mathrm{~cm})$.

\subsection{Fruit weight $(g)$}

Data pertaining to fruit weight as influenced by age of seed, plasma treatments and their interactions are presented in Table 4. Fruit weight differed significantly due to aged seed. The highest fruit weight (12.60 g) was observed in one year old seed. While lowest fruit weight (11.94 g) was recorded in two year old seed.

A significant improvement in fruit weight was observed due to different exposure of plasma over control. Seed exposed to plasma for 12 minutes recorded highest fruit weight (13.38 g) which was at par with 15 minutes $(12.81 \mathrm{~g}), 9$ minutes (12.80 g) and 6 minutes ( $12.40 \mathrm{~g}$ ) treatment. The seed which was kept under vacuum and not exposed to plasma recorded lowest fruit weight (11.45 g) compared to plasma treated seeds. The lowest fruit weight (11.18 g) was recorded in control seed where no vacuum and no plasma treatment were given.

Productivity and quality of okra fruits largely depends on fruit weight. Fruit weight was maximum (12.60 g) in crop raised from one year old seeds and minimum (11.94 g) in crop raised from two year old seeds. The reduction in fruit weight could be attributed to seed ageing. Increase in fruit weight was shown significant in all the plasma treatments over the untreated seeds. Maximum average fruit weight (13.38 g) was observed in seeds treated with 12 minutes plasma exposure and minimum average fruit weight ( $11.18 \mathrm{~g}$ ) was recorded in control. The results are in line with Jiafeng et al. (2014) as according to them better growth of plasma treated seeds at booting stage in wheat result in longer root, higher height and heavier weight. However, they were better at absorbing water and nutrition, and could get maximum light for photosynthesis as a result could increase physiological activities of wheat. Interaction effects between aged and plasma treatments were 


\begin{tabular}{|c|c|c|c|c|c|c|c|c|c|}
\hline \multirow{4}{*}{$\begin{array}{l}\text { Plasma } \\
\text { treatment } \\
\text { Durations } \\
\text { (P) }\end{array}$} & \multicolumn{3}{|c|}{ Fruit length } & \multicolumn{3}{|c|}{ Fruit diameter } & \multicolumn{3}{|c|}{ Fruit weight } \\
\hline & \multicolumn{3}{|c|}{$(\mathrm{cm})$} & \multicolumn{3}{|c|}{$(\mathrm{cm})$} & \multicolumn{3}{|c|}{ (g) } \\
\hline & \multirow{2}{*}{$\begin{array}{l}\text { One year } \\
\text { seed }\left(A_{1}\right)\end{array}$} & \multirow{2}{*}{$\begin{array}{l}\text { Two year } \\
\text { seed }\left(A_{2}\right)\end{array}$} & Mean & \multirow{2}{*}{$\begin{array}{l}\text { One year } \\
\text { seed }\left(A_{1}\right)\end{array}$} & \multirow{2}{*}{$\begin{array}{l}\text { Two year } \\
\text { seed }\left(A_{2}\right)\end{array}$} & \multirow{2}{*}{$\begin{array}{c}\text { Mean } \\
(\mathrm{P})\end{array}$} & \multirow{2}{*}{$\begin{array}{l}\text { One year } \\
\text { seed }\left(A_{1}\right)\end{array}$} & \multirow{2}{*}{$\begin{array}{l}\text { Two year } \\
\text { seed }\left(A_{2}\right)\end{array}$} & \multirow{2}{*}{$\begin{array}{c}\text { Mean } \\
(\mathrm{P})\end{array}$} \\
\hline & & & $(P)$ & & & & & & \\
\hline Vacuum & 19.26 & 16.55 & 17.90 & 2.27 & 1.97 & 2.12 & 11.71 & 11.19 & $11.45^{\mathrm{ab}}$ \\
\hline 3 minutes & 15.82 & 15.9 & 15.86 & 2.21 & 2.14 & 2.18 & 12.14 & 11.59 & $11.87^{a b c}$ \\
\hline 6 minutes & 17.11 & 17.13 & 17.12 & 2.30 & 2.02 & 2.16 & 12.71 & 12.09 & $12.40^{\mathrm{bcd}}$ \\
\hline 9 minutes & 16.39 & 17.47 & 16.93 & 2.39 & 2.13 & 2.26 & 13.21 & 12.40 & $12.80^{\text {cd }}$ \\
\hline 12 minutes & 16.04 & 17.03 & 16.54 & 2.41 & 2.24 & 2.32 & 13.74 & 13.02 & $13.38^{d}$ \\
\hline 15 minutes & 15.96 & 18.12 & 17.04 & 2.23 & 2.12 & 2.18 & 13.20 & 12.42 & $12.81^{c d}$ \\
\hline $\begin{array}{l}\text { Control } \\
\text { (untreated) }\end{array}$ & 15.82 & 15.72 & 15.77 & 2.10 & 1.91 & 2.01 & 11.52 & 10.84 & $11.18^{a}$ \\
\hline Mean & 16.63 & \multirow[t]{2}{*}{16.84} & & 2.27 & \multicolumn{2}{|l|}{2.07} & $12.60^{A}$ & $11.94^{\mathrm{B}}$ & \\
\hline \multicolumn{9}{|l|}{ (A) } & \\
\hline \multirow[t]{3}{*}{$\mathrm{CD}(p=0.05)$} & (A) & \multicolumn{2}{|c|}{ NS } & \multicolumn{3}{|c|}{ NS } & \multicolumn{3}{|c|}{0.60} \\
\hline & $(P)$ & \multicolumn{2}{|c|}{ NS } & \multicolumn{3}{|c|}{ NS } & \multicolumn{3}{|c|}{1.12} \\
\hline & $(\mathrm{AxP})$ & \multicolumn{2}{|c|}{ NS } & \multicolumn{3}{|c|}{ NS } & \multicolumn{3}{|c|}{ NS } \\
\hline
\end{tabular}

found to be non-significant for fruit weight.

\subsection{Fruit yield plant ${ }^{1}$}

Data pertaining to fruit yield plant ${ }^{-1}$ as influenced by age of seeds, plasma treatments and their interactions are presented in Table 5. The maximum fruit yield plant ${ }^{-1}(222.98 \mathrm{~g})$ was observed in one year old seeds and the minimum fruit yield plant $^{-1}(217.95 \mathrm{~g})$ was recorded in two year old seeds.

A significant improvement in fruit yield plant ${ }^{-1}$ was observed due to different exposure of plasma over control. Seed exposed to plasma for 12 minutes recorded maximum fruit yield plant ${ }^{-1}$ $(229.64 \mathrm{~g})$ which was at par with 9 minutes $(225.88 \mathrm{~g})$ and 6 minutes $(221.96 \mathrm{~g})$ treatment. The seed which was kept under vacuum and not exposed to plasma recorded minimum fruit yield per plant ( $214.75 \mathrm{~g}$ ) compared to plasma treated seeds .The minimum fruit yield plant $^{-1}(212.40 \mathrm{~g})$ was observed in control seed where no plasma treatment were given.

Non-significant interaction effects due to age of seed and plasma exposure time were observed for fruit yield plant ${ }^{-1}$.

\subsection{Fruit yield plot ${ }^{-1}$}

The result on fruit yield plot ${ }^{-1}$ as influenced by age of seed, plasma treatments and their interactions are presented in Table 5. The maximum fruit yield plot ${ }^{-1}(7.71 \mathrm{~kg})$ was observed in one year old seeds and the minimum fruit yield plot $^{-1}(6.43$ $\mathrm{kg})$ was recorded in two year old seeds.

While comparing the exposure time of plasma to the seed, it significantly influenced the fruit yield plot $^{-1}$. Maximum fruit yield plot $^{-1}$ was, however, observed in the seed exposed to plasma for 12 minutes $(8.27 \mathrm{~kg})$ and the seed exposed for 9 minutes to plasma showed significant minimum fruit yield $\operatorname{plot}^{-1}(7.54 \mathrm{~kg})$, which was at par with 15 minutes $(7.24 \mathrm{~kg})$ and 6 minutes $(7.22 \mathrm{~kg})$ treatment. The seed which was kept under vacuum and not exposed to plasma recorded minimum fruit yield plot $^{-1}(6.36 \mathrm{~kg})$ compared to plasma treated seeds. The minimum fruit yield plot $^{-1}(5.93 \mathrm{~kg})$ was recorded in control seed where no vacuum and no plasma treatment were given. Interaction effects of age of seed and plasma exposure time were statistically non significant at $5 \%$ level of significance.

\subsection{Fruit yield $h a^{-1}$}

The data on fruit yield ha ${ }^{-1}$ as influenced by age of seed, plasma treatments and their interactions are presented in Table 5. The maximum fruit yield ha $\mathrm{h}^{-1}$ (140.09 q) was observed in one year old seeds and the minimum fruit yield ha-1 $(116.87 \mathrm{q})$ was recorded in two year old seeds.

Fruit yield ha-1 ${ }^{-1}$ were significantly differed due to different exposure of plasma on okra seed. Seed exposed to plasma for 12 minutes recorded maximum fruit yield ha ${ }^{-1}(150.37 \mathrm{q})$ and the seed exposed for 9 minutes to plasma showed significant minimum fruit yield ha-1 $(137.15 \mathrm{q})$, which was at par with 15 minutes (131.63 q) and 6 minutes (131.27 q) treatment. The seed which was kept under vacuum and not exposed to plasma recorded minimum fruit yield ha ${ }^{-1}(115.71 \mathrm{q})$ compared to plasma treated seeds. The minimum fruit yield ha-1 $(107.90 \mathrm{q})$ was observed in control seed where no treatment were given. The interaction effects due to age of seed and plasma exposure time were found to be non-significant at $5 \%$ level 


\begin{tabular}{|c|c|c|c|c|c|c|c|c|c|}
\hline \multirow{2}{*}{$\begin{array}{l}\text { Plasma } \\
\text { treatment } \\
\text { Durations }\end{array}$} & \multicolumn{3}{|c|}{ Fruit yield plant $^{-1}$} & \multicolumn{3}{|c|}{ Fruit yield plot ${ }^{-1}$} & \multicolumn{3}{|c|}{ Fruit yield ha-1 } \\
\hline & \multicolumn{3}{|c|}{ (g) } & \multicolumn{3}{|c|}{ (kg) } & \multicolumn{3}{|c|}{ (q) } \\
\hline \multirow[t]{2}{*}{$(\mathrm{P})$} & \multirow{2}{*}{$\begin{array}{l}\text { One year } \\
\text { seed }\left(A_{1}\right)\end{array}$} & \multirow{2}{*}{$\begin{array}{l}\text { Two year } \\
\text { seed }\left(A_{2}\right)\end{array}$} & Mean & \multirow{2}{*}{$\begin{array}{l}\text { One year } \\
\text { seed }\left(A_{1}\right)\end{array}$} & \multirow{2}{*}{$\begin{array}{l}\text { Two year } \\
\text { seed }\left(A_{2}\right)\end{array}$} & Mean & \multirow{2}{*}{$\begin{array}{l}\text { One year } \\
\text { seed }\left(A_{1}\right)\end{array}$} & \multirow{2}{*}{$\begin{array}{l}\text { Two year } \\
\text { seed }\left(A_{2}\right)\end{array}$} & \multirow{2}{*}{$\begin{array}{c}\text { Mean } \\
(\mathrm{P})\end{array}$} \\
\hline & & & $(P)$ & & & $(\mathrm{P})$ & & & \\
\hline Vacuum & 217.53 & 211.98 & $214.75^{\mathrm{ab}}$ & 7.00 & 5.72 & $6.36^{\mathrm{a}}$ & 127.35 & 104.06 & $115.71^{\mathrm{a}}$ \\
\hline 3 minutes & 220.75 & 214.48 & $217.61^{\mathrm{ab}}$ & 7.62 & 6.16 & $6.89^{b}$ & 138.61 & 112.07 & $125.34^{\mathrm{b}}$ \\
\hline 6 minutes & 225.20 & 218.73 & $221.96^{\mathrm{b}-d}$ & 7.83 & 6.62 & $7.22^{\mathrm{bc}}$ & 142.28 & 120.27 & $131.27^{\mathrm{bc}}$ \\
\hline 9 minutes & 228.78 & 222.98 & $225.88^{c d}$ & 8.12 & 6.97 & $7.54^{c}$ & 147.67 & 126.63 & $137.15^{c}$ \\
\hline 12 minutes & 231.53 & 227.75 & $229.64^{d}$ & 9.03 & 7.52 & $8.27^{d}$ & 164.09 & 136.65 & $150.37^{d}$ \\
\hline 15 minutes & 222.05 & 219.98 & $221.01^{b c}$ & 7.66 & 6.82 & $7.24^{\mathrm{bc}}$ & 139.33 & 123.92 & $131.63^{\mathrm{bc}}$ \\
\hline $\begin{array}{l}\text { Control } \\
\text { (untreated) }\end{array}$ & 215.05 & 209.75 & $212.40^{\mathrm{a}}$ & 6.67 & 5.20 & 5.93a & 121.32 & 94.47 & $107.90^{\mathrm{a}}$ \\
\hline Mean & $222.98^{\mathrm{A}}$ & $217.95^{\mathrm{B}}$ & & $7.71^{\mathrm{A}}$ & $6.43^{\mathrm{B}}$ & & $140.09^{A}$ & $116.87^{\mathrm{B}}$ & \\
\hline \multicolumn{10}{|l|}{ (A) } \\
\hline \multirow[t]{3}{*}{$\mathrm{CD}(p=0.05)$} & (A) & \multicolumn{2}{|c|}{4.30} & \multicolumn{3}{|c|}{0.28} & \multicolumn{3}{|c|}{5.10} \\
\hline & $(\mathrm{P})$ & \multicolumn{2}{|c|}{8.04} & \multicolumn{3}{|c|}{0.52} & \multicolumn{3}{|c|}{9.55} \\
\hline & $(\mathrm{AxP})$ & \multicolumn{2}{|c|}{ NS } & \multicolumn{3}{|c|}{ NS } & \multicolumn{3}{|c|}{ NS } \\
\hline
\end{tabular}

of significance

The yield and yield components viz., fruit yield plant ${ }^{-1}$, fruit yield plot $^{-1}$ and fruit yield ha-1 differed significantly between one year and two year old seeds. The highest fruit yield plant $^{-1}$, fruit yield plot $^{-1}$ and fruit yield ha-1 $(222.98 \mathrm{~g}, 7.71$ $\mathrm{kg}$ and $140.09 \mathrm{q}$ ) was recorded in one year old seeds while lowest was observed (217.95 g, $6.43 \mathrm{~kg}$ and $116.87 \mathrm{q}$ ) in two year old seeds, respectively. Similar results were observed by Hussaini et al. (1988) and they recorded decrease in fruit yield of one year stored maize seeds. This difference in relation to various yield attributing characters may be due to difference in vigour levels as reported by Funk et al. (1962) in maize. Rodriguez and McDonald (1989) observed reduced plant growth and yield in low vigour bean seeds. Increased yield is one of the main objectives of seed plasma. Maximum yield (229.64 g plant $^{-1}, 8.27 \mathrm{~kg} \mathrm{plot}^{-1}$ and $150.37 \mathrm{q} \mathrm{ha}^{-1}$ ) was observed in seeds treated with 12 minutes plasma exposure. On the other hand, untreated control recorded minimum $(212.40 \mathrm{~g}, 5.93 \mathrm{~kg}$ and $107.90 \mathrm{q})$ yield plant ${ }^{-1}$, plot ${ }^{-1}$ and $\mathrm{ha}^{-1}$ respectively. The increase in fruit yield may be due to early emergence, higher total emergence, more number of flowers plant $^{-1}$, increase in fruit weight and more number of fruits plant $^{-1}$. The results are in conformity with Krapivina et al. (1994); Zhou et al. (2009); Jiafeng et al. (2014). They reported increase in yield due to seed plasma in soybean, tomato and wheat, respectively. The study of interaction effects between ageing and plasma treatments was found to be non-significant for yield characters.

\section{Conclusion}

Age of the seed greatly influenced the quality and yield of okra. Seeds treated with 12 min plasma treatment proved its potential over other plasma treatments and control (untreated seeds) in both one year and two year old seeds. Hence, seed treatment with 12 min plasma exposure can be used as a beneficial pre-sowing treatment to enhance the physiological, growth and yield in okra.

\section{References}

Ariyo, O.J., 1989. Variation and heritability of fifteen characters in okra (Abelmoschus esculentus (L.) Moench). Tropical Agriculture Journal (Trinidad) 67, 1990. 215-216.

Ariyo, O.J., 1992. Factor analysis of component of yield and vegetative traits in okra. Indian Journal of Agricultural Sciences 62, 83-84.

Baskin, J.M., Baskin, C.C., 1998. Ecology, biogeography and evolution of dormancy and germination. Academic Press, San Diego, CA.

Dubinov, A.E., Lazarenko, E.M., Selemir, V.D., 2000. Effect of glow discharge air plasma on grain crops seed. IEEE Transactions on Plasma Science 28(1), 180-183.

Edje, O.T., Burris, J.S., 1970. Seedling vigour soybean. Proceedings of Association of Seed Analysts 60, 149-157.

Filatova, I., Azharnok, V., Gorodetskaya, E., Shedikova, O., Shik, A., 2010. Plasma radiowave stimulation of plant seeds germination and inactivation of pathogenic microorganisms. 2010. International Symposium on 
Plasma Chemistry conference.

Filatova, I., Azharonok, V., Lushkevich, V., Zhukovsky, A., Gadzhieva, G., Spasic, K., Zivkovic, S., Puac, N., Lazovic, S., Malovic, G., Petrovic, Z.L., 2013. Plasma seeds treatment as a promising technique for seed germination improvement. lasi Plasma Advanced Research Center 14-19.

Funk, C.R., Anderson, T.C., Johenson, M.W., Atkensons, 1962. Effect of seed source and seed age on field and laboratory performance of field corn. Crop Science 2, 318-320.

Griesser, S.S., Prakas, S., Griesser, H.J., 2011. Plasma discharge treatment for improved germination of seeds and killing of fungal spores on seed coats. Final project report to the Australian Flora Foundation. Ian Wark Research Institute, University of South Australia, Mawson Lakes, SA 5095.

Hammon, S., Van Sloten, D.H., 1989. Characterization and evaluation of okra. The use of plant genetic resources. 173-174.

Heydecker, W., 1972. In: Roberts, E.H. (Ed.), Vigour and viability of seeds, Chapman Hall: London, 246.

Hussaini, S.H., Ahmed, Z.A., Dhanrai, A., 1988. The effect of accelerated ageing on germination, vigour and yield of maize. Seed Research 16(1), 68-75.

Jiafeng, J., Lu, Y., Jiangang, L., Ling, L., Xin, H., Shao, H., Dong, Y., 2014. Effect of seed treatment by cold plasma on the resistance of tomato to Ralstonia solanacearum (Bacterial Wilt). Plos One 9(5), 1-6.

Jiafeng, J., Xin, H., Ling, L., Jiangang, L., Hanliang, S., Qilai, X., Renhong, Y., Yuanhua, D., 2014. Effect of cold plasma treatment on seed germination and growth of wheat. Plasma Science and Technology 16(1), 54-57.

Karuna, M.N., Aswathaiah, B., 1989. Effect of seed vigour on field performance in beetroot and carrot. Seed and Farms 14(9-10), 40-46.

Kaul, T., Lal, G., Peter, K.V., 1978. Correlation and path coefficient analysi of components of earliness, pod yield and seed yield in okra. Indian Journal of Agricultural Sciences 48(8), 459-463.

Kochhar, S.L., 1986. Tropical Crops. A text book of economic botany. Macmillan 1986. Indian Ltd. 263-264.

Krapivina, S.A., Alexander, K.F., Tatiana, N.L., Andrei, B., 1994. Gas plasma treatment of plant seeds. United States Patent, 54-56.

Luis Felipe, V.P., Antonio, A.L., Francisco, A.P., 2010. Germination and hardseedness of seeds in okra. Horticultura Brasileiram 28, 232-235.
Mereddy, R., Wu, L., Hallgren, S.W., Wu, Y., Conway, K.E., 2000. Solid Matrix Priming improves seedling vigour of okra seeds. Oklahoma Academy of Science 80, 33-37.

Mishra, R.S., Chhonkar, V.S., 1979. Genetic divergence in Okra. Indian Journal of Agricultural Sciences 49, 244-246.

Rodriguez, A., McDonald, M.B., 1989. Seed quality influence on plant growth and nitrogen fixation on red field bean. Crop Science 29, 1309-1314.

Schuch, L.O.B., Lin, S.S., 1982. Effect of accelerated ageing on performance of seed and plant of plant. Pesquia Agropecuria Brasileria 17, 1163-1170.

Sera, B., Gajdova, I., Cernak, M., Gavril, B., Hnatiuc, E., Kovacik, D., Kriha, V., Slama. J., Sery, M., Spatenka, P., 2012. How various plasma sources may affect seed germination and growth. IEEE Plasma Science 39(7), 1365-1369.

Sera, B., Stranak, V., Sery, M., Tichy, M., Spatenka, P., 2008. Germination of Chenopodium album in response to microwave plasma treatment. Plasma Science and Technology 10(4), 506-510.

Setubal, J.W., Zanin, A.C.W., Nakagawa, J., 1994. Efeitos de metodos de colheita e da localizacao dos frutos na planta sobre a ocorrencia de sementes duras em quiabeiro (Abelmoschus esculenthus (L.) Moench). Sci Agric 51, 490-493.

Singh, K.B., Singh, H.N., 1977. Path coefficient analysis for yield in okra. Indian Journal of Agricultural Sciences 49, 244-246.

Spatenka, P., Stranak, V., Sery, M., Tichy, M., Sera, B., 2008. Germination of Chenopodium album in response to microwave plasma treatment. Plasma Science and Technology 10(4), 506-510.

Tekroni, D.M., Egli, D.B., Wickham, D.A., 1989. Corn seed vigour effect on no tillage field performance II plant growth and grain yields. Crop Science 29, 1528-1531.

Zhou, Z., Huang, Y., Yang, S., Chen, W., 2011. Introduction of a new atmospheric pressure plasma device and application on tomato seeds. Agricultural Sciences 2(1), 23-27.

Zhou, Z.W., Huang, Y.F., Yang, S.Z., Deng, M.S., 2009. Effects of plasma treatment on yield and quality of Hongza (tomato) 10 seeds. Guizhou-Agricultural-Sciences 12, 58-61.

Zivkovic, S., Puac, N., Giba, Z., Grubisic, D., Petrovic, Z., 2004. The stimulatory effect of non-equilibrium (low temperature) air plasma pre-treatment on light-induced germination of Paulownia tomentosa seeds. Seed Science and Technology 32(3), 693-701. 